Volume 6 Issue 1, 2020

P-ISSN : 2528-360X, E-ISSN : 2621-6159

Website: https://www.jurnal-umbuton.ac.id/index.php/Pencerah

\title{
Pengaruh Alat Pencetakan Tahu Terhadap Produktifitas Tahu di Desa Waegeran Kabupaten Buru
}

\author{
${ }^{1}$ Muhamad Bula, ${ }^{1}$ Iyas Wali
}

Email: muhammadbulauniqbu@gmail.com

\begin{abstract}
The problem described in this study is how much tofu production is produced, the value of depreciation of equipment and income of tofu craftsmen Waegeren Village Buru Regency in producing tofu using modern tofu printing equipment technology. From the problems outlined, in the goel the goalto be archived is know the level of tofu production produced by tofu craftsmen Waegeren Village Buru District every day, knowing the value of depreciation of tofu printing equipment each month based on economic analysis theory, and knowing the amount of tofu craftsman income each month. The research method uses the method of observation, which is a method of research carried out without any intervention at all from the researchers, the researchers conducted observations and interviews at the tofu industry craftsman in Waegeren Village. The results obtained, tofu production using modern technology by tofu craftsmen Waegeren Village Buru Regency per day only reached $150 \mathrm{~kg}$ or equivalent to 225 pieces of tofu. Meanwhile, the cost of equipment depreciation and tofu craftsman income every month is Rp. 45,900,000 and Rp. 9,855,000.
\end{abstract}

Keywords: Production; Tofu; Equipement

\begin{abstract}
Abstrak
Abstrak Masalah yang diuraikan pada penelitian ini adalah seberapa besar jumlah produksi tahu yang dihasilkan, nilai penyusutan peralatan dan pendapatan pengrajin tahu Desa Waegeren Kabupaten Buru dalam memproduksi tahu menggunakan teknologi alat cetak tahu modern. Dari masalah yang diuraikan, maka tujuan yang hendak dicapai yaitu mengetahui tingkat produksi tahu yang dihasilkan oleh pengrajin tahu Desa Waegeren Kabupaten Buru tiap harinya, mengetahui besar nilai penyusutan alat teknologi cetak tahu tiap bulannya berdasarkan teori analisa ekonomi, dan mengetahui besar pendapatan pengrajin tahu tiap bulannya. Metode penelitian menggunakan metode observasi, yaitu suatu metode yang dilakukan tanpa adanya ikut campur pneliti terhadap objrk yang sedang dikaji, peneliti melakukan pengamatan dan wawancara di tempat pengrajin industri tahu Desa Waegeren. Hasil yang diperoleh, produksi tahu menggunakan teknologi moderen oleh pengrajin tahu Desa Waegeren Kabupaten Buru perharinya baru mencapai $150 \mathrm{~kg}$ atau setara dengan 225 potong tahu. Sementara itu, biaya penyusutan peralatan dan pendapatan pengrajin tahu tiap bulannya sebesar Rp. 45.900 .000 dan Rp. 9.855.000.

Kata Kuci: Produktifitas; Tahu; Pencetakan
\end{abstract}

\section{PENDAHULUAN}

Perkembangan teknologi di berbagai bidang seperti industri makanan, informasi teknologi, permesinan dan pekerjaan sipil semakin pesat. Perkembangan teknologi bukan hanya terjadi pada daerah yang telah maju dunia informasinya semisal daerah perkotaan tetapi telah merambah sampai pada daerah pedesaan. Perkembangan teknologi di daerah pedesaan terjadi seiring dengan kebutuhan masyarakat dalam mengembangkan dunia usahanya. Dalam masyarakat buru secara umum bidang usaha sangat bervariasi hal ini juga dipengaruhi oleh berbagai tradisi dan budaya yang multi etnis (Belinda 2019).

\footnotetext{
${ }^{1}$ Universitas Iqra Buru, Indonesia
} 
Sebagai contoh, pemanfaatan teknologi pembuatan tahu menggunakan teknologi moderen di Desa Waegeren Kabupeten Buru.

Desa Waegeren secara administratif pemerintahan terletak pada Kecamatan Waeapo Kabupaten Buru, secara geografis jarak tempuh dari Kota Namlea yang merupakan kota Kabupaten Buru sekitar $32 \mathrm{~km}$ dengan waktu 9 jam menggunakan transportasi darat. Dalam memenuhi kebutuhan hidupnya, masyarakat Desa Waegeren banyak berprofesi sebagai petani dan ada pula yang berprofesi sebagai pengrajin pembuat tahu menggunakan teknologi alat cetak tahu yang sudah modern.

Proses pembuatan tahu menggunakan teknologi moderen, memiliki suatu hambatan yang dapat mempengaruhi produktifitas para pengusaha tahu Desa Waegeren dalam memproduksi tahu. Hambatan itu meliputi, lemahnya pengetahuan tenaga kerja dalam mengoperasikan dan merawat peralatan serta pemilihan bahan dasar tahu yang tidak bermutu. Akibat dari hambatan ini, maka akan mempengaruhi kuantitas dan kualitas tahu yang diproduksi. Tahu yang diproduksi sangat tidak maksimal, membutuhkan waktu yang cukup lama dan tahu yang diproduksi tidak baik untuk dikonsumsi oleh konsumen serta pendapatan yang dihasilkan sangat kecil.

Para pekerja yang tersebar atau yang direkrut oleh pemilik pabrik tahu merupakan anggota keluarga si pemilik, yaitu saudara dan anak para pemilik. Tingkat pendidikan umumnya relatif rendah yaitu hanya setingkat sekolah dasar. Sedangkan ketrampilan yang dimiliki diperoleh dari pengalaman setelah lama bekerja pada perusahaan tersebut. Dua orang pekerja mampu memproduksi $100 \mathrm{~kg}$ kedelai menjadi tahu dalam waktu sehari. Alat penggiling moderen mampu beroperasi dalam satu hari hingga $150 \mathrm{~kg}$ kedelai yang dapat digiling bahkan bisa sampai lebih, namun disesuaikan dengan tenaga kerja yang dimiliki pabrik tersebut.

Setelah dilakukan tinjauan dari proses pengolahan tahu yang dilakukan oleh masyarakat Desa Waegeren, maka ditemukan suatu permasalahan yaitu seberapa besar jumlah produksi tahu yang dihasilkan tiap harinya, nilai penyusutan peralatan dan pendapatan pengrajin tahu Desa Waegeren dalam memproduksi tahu menggunakan teknologi alat cetak tahu modern.

Dari latar belakang di atas maka yang menjadi rumusan masalah dalam penelitian ini adalah menegetahui tingkat produsi tahu yang dihasilkan oleh pengrajin tahu Desa Waegeren tiap harinya, mengetahui besar nilai penyusutan alat teknologi cetak tahu tiap bulannya berdasarkan teori analisa ekonomi, dan mengetahui besar pendapatan pengrajin tahu tiap bulannya.

Untuk memecahkan permasalahan dan diperolehnya hasil dalam kerangka menjawab tujuan yang diangkat, maka kajian teori sebagai dasar acuan penyelesaian masalah dan memperoleh tujuan perlu dilakukan. Kajian teori menyangkut penelitian-penelitian yang pernah dilakukan dibeberapa tempat.

\section{TINJAUAN PUSTAKA}

\subsection{Penelitian yang berhubungan}

Cafah \& fadhil (2009), melakukan penelitian tentang analisis biaya produksi terhadap usaha produksi tahu di pabrik tahu Bandung. Penelitian cafah dan fadhil mengkaji dan menganaisis biaya dan kelayakan usaha pembuatan tahu.

Data dikumpulkan dengan menngunakan meode observasi dan wawancara terhadap pelaku usaha. Hasil yang ditemukan dalam penelitian tersebut adalah usaha produksi tahu di Bandung memerlukan dana investasi awal sebesar Rp. 672.000 .000 dan biaya keseluruhan 
untuk produksinya dalam pertahun adalah Rp. 1. 832. 587.827.700. kemudian NPV yang dihasilkan dari perhitunganya adalah Rp. 1. 832. 574.344, dengan IRR $61,99 \%$. Serta nilai NET B/C adalah 3,73.

Penelitian kedua yakni Santoso yang meneliti tentang abnalisis pendapatan dan biaya produksi agroindustry Tahu di desa Pandansari. Ia meneliti dengan tujuan mengetahui besarnya biaya produksi dan pendapatan yang diburtuhkan oleh pengrajin tahu di desa Pandansari. Metode yang digunakan pada penelitian ini adalah metode survai denga pengambilan sampel secara sengaja (purpose Sampling) sampel yang diambil sebanyak 20 orang pengrajin tahu dari 198 pengarjin tahu yang tersebar.

Pengambilan data sama halnya pada penelitian cafah dan fadhil yakni wawncara terhadap sampel yang sudah di ambil. Kemudian data dianalisis sesuai dengan teori-teori ahli untuk enjawab rumusan msalah. Hasil yang didapta yakni dalam memproduksi tahu pelaku usaha mememrlukan modal dalam satu kali usaha idustri adalah Rp. 320, 288. 30 dengan pendapatan bersih sebesar Rp. 72.313.000.

\subsection{Defenisi dan Tahapan Proses Pembuatan Tahu}

Kata Tahu berasal dari Cina tao-hun atau tokwa Kata tao atau teu berarti kacang. Untuk membuat tahu maka yang dibutuhakan adalah kedalai (kuning, putih), sedangkan hu atau kwa rusak atau hancur menjadi bubur jadi tahu adalah makanan yang dibuat dengan bahan olahan dari kedalai yang dihancurkan menjadi bubur (Kasyanto: 1999). Sementara itu menurut Suorapti (2005) tahu dibuat dari kacang kedelai yang dilakukan proses penggumpalan (penegndapan). Kulaitas tahu juga berbeda antara satu dan yang lainya hal ini dipengaruhi oleh cara pengendapan dalam proses pembuatanya.
Lebih lanjut Surapti 2005 menjelaskan tentang proses pembuatan tahu. Bahwa dalam proes pembuaanya kacang kedelai dilakukan proses pengumpalan atau pengendapan. Tahu diproduksi dengan memenfaatkan sifat protein, yaitu akan menggumpal bila beraksi dengan asam. Penggumpalan protein oleh asam cuka akan berlangsung secara cepat dan serentak diseluruh bagian cairan sari kedelai akan terperangkap didalamnya. Pengeluaran air yang terperangkap tersebut dapat dilaukukan dengan memeberikn tekanan, semakin banyak air yang dapat dikeluarkan dari gumpalan protein, maka gumpalan protein itulah yang diseburt dengan "tahu".

Standar pembuatan tahu meneurut Surapti 2005

\section{a. Air}

Air meupakan komponen terbesar dalam produk tahu yakni, meliputi 80 $85 \%$, namun air tidak dapat ditetapkan sebagai karakteristik dalam penentuan kulaitas tahu.

b. Protein

Protein mrupakan komponen utama dalam menentukan produksi dan kualitas tahu. Dalam standar mutu tahu ditetapkan kadar minmal protein dalam tahu adalah $9 \%$ dari berat tahu.

c. Abu

Abu dalam tahu merupakan unsur mineral yang terkandung dalam kedelai, bila kadar abu terlalu tinggi berarti telah tercemar oleh kotoran misalnya, tanah, pasir. Garam NaCI termasuk dalam kelompok abu.

\section{d. Serat Kasar}

Serat kasar dalam produk tahu berasal dari ampas kedelai dan kunyit (pewarna). Adapun kadar maksimal serat yang diperbolehkan adalah $0,1 \%$ dari berat tahu.

e. Logam 
Logam berbahaya (As, $\mathrm{Pb}, \mathrm{Mg}, \mathrm{Zn}$ ) yang terkandung dalam tahu antara lain berasal dari air yangtidak mememnuhi standar minimum.

\section{f. Zat pewarna}

Zat pewarna yang digunakan dalam pembuatan tahu yakni pewarna alami yakni kunyit.

\section{g. Bau dan rasa}

Adanya penyimpangan baud an rasa memanndakan telah terjadi kerusakan (basi atau busuk) atau pencemarn bahan lain.

h. Lendir dan jamur

Keberadaan lender dan jamur menandakkan kerusakan dalam produksi tahu.

\section{i. Bahan pengawet \\ j. Bakteri coli}

Bakteri ini berasal dari pembuatan tahu jika produksi air dalam pembuaan tahu tidak memenuhi standar maksimum.

Ada tiga hal yang memepengaruhi kulitas tahu antara lain:
a. Tingkat kepadatan
b. Adanya bau asam
c. Pennampian.

Pada wilayah Maluku khususnya Kabuapaten buru proses pembuatan tahu masih dalam tataran produksi tradisional dan masih membutuhkan tenaga manusia dalam memproduksi tahu. Namun pada proses pebuatan tahu di Desa Wegeraen teknilogi yang digunakan merupakan teknologi modern namun kenyataanya dalam proses pembuatanya masih ada tantangan dan hambatan dalam berproduksi.

Tahapan dalam mengolah tahu adalah langkah awal yang dilakukan merendam kedelai dalam air selanjutnya kedelai yang telah direndam tersebut dimasukkan kedlam mesin penggiling hingga kedelai tersebut berbentuk halus.
Selanjutnya kedelai yang sudah berbentuk halus diolah dengan cara dimasak dengan mesin ataupun secara manual. Selanjutnya setelah matang maka diangkat kemudian dicetak sesuai dengan bentuk. Langkah selanjutnya dipotong dan dimasukan dalam tempat penyimpangan.

Sedikit sekali informs tentang awal mula cara pembuatan tahu. Dari beberapa teori yang ada dalam referensi media cetak maupu onlaine tentang awal mula pembuatan tahu namun informasi sejarah masih sangat langka. Dari beberap refernsi yang ada ada tiga sejarah munculnya penemuan tahu tersebut.

a. Tahun 162 diteukan di cina oleh Loard Liu An yakni seorang bangsawan (pangeran) pada dinasti han

b. Bubur kedelai yang tumpah saat mendidih yang bercamour dengan air laut yang tak murni. Garam laut tersebut mengandung kalsium dan magnesium bercampur dengan susu kedelai sehingga membeku dan menghasikan bahan gell seperti tahu.

\subsection{Analisa Ekonomi}

Analisa ekonomi pada suatu usaha atau indsutri sangat penting untuk dilakukan. Sarwono (2004) tentang analisa finansial dan ekonomi, analisa finansial dilakukan pada suatu usaha atau industri dimaksudkan untuk menganalisa suatu usaha dari lembaga atau badan yang menangani atau memunyai kepetinagan langsung dalam usaha yang digeluti. Perbandingan antara pengeluaran uang dengan pemasukan uang dan hasil dari analisa ini disebut the privat returns.

Pengolahan kedelai menjadi tahu terdapat investasi anggran yang digunakan pada susatu usaha produksi maupun pengolahan bahan makanan dan perkiraan keuntungan/pendapatan yang harus doperoleh daam usaha tersebut. Selain itu,juga analisa ekonomi dari usaha pembuatan tahu belum bersifat tetap 
yang berarti berubah sesuai dengan keaddaan dan kondisi pasar yang ada atau kebutuhan masayarakat konsumen. Contoh analisa ekonomi dalam menaganlisis pembuatan tahu/ usaha produksi tahu yakni:

a. Biaya produksi

Biaya produksi merupakan seluruh biaya yang diperlukan dalam kegiatan pembuatan tahu, yang meliputi biaya penyusutan, biaya peralatan, biaya bahan baku, dan biaya tenaga kerja.

b. Biaya Penyusutan Peralatan

Biaya penyusutan dihitung berdasarkan nilai baru (harga beli) di bagi dengan Jangka Usia Ekonomi (JUE) pemakaian alat-alat, contoh perhitungan biaya penyusutan.

\section{METODE PENELITIAN}

Pada penelitian ini peneliti menggunakan metode observasi yakni metode yang digunakan tanpa adanya ikut campur peneliti terhadap narasumber atau objek ang sedang dikaji. Objek observasi berupa fenomenafenomena yang dibiarkan terjadi secara alamiah (Azwar, 2010:19). Data perolehan observasi yang digunakan untuk mendukung proses kajian dalam penelitian ini adalah :

\section{a. Bahan Dasar Tahu}

Bahan dasar pembuatan tahu menggunakan kacang kedelai berkualitas dengan ciri-ciri berbiji besar dengan bobot 100 biji lebih dari 13 gram, berbiji sedang bila bobot 100 bijinya antara 11 - 13 gram, dan kedelai berbiji kecil bila bobot 100 bijinya antara 7 - 11 gram. Syarat mutu kedelai untuk memproduksi tahu, kualitas pertama adalah sebagai berikut:

1) Bebas dari sisa tanaman (kulit palang, potongan batang/ ranting, batu, kerikil, tanah atau biji bijian)

2) Biji kedelai tidak luka atau bebas serangan hama dan penyakit
3) Biji kedelai tidak memar

4) Kulit biji kedelasi tidak keriput

Bahan baku lainnya yang diperlukan dalam pembuatan tahu adalah biang tahu atau bubuk batu tahu (sulfat kapur), asam cuka (kadar $5 \%$ ) dan air kelapa. Selain mayon atau air sisa hasil endapan sari tahu yang didiamkan selama satu hari. Air sisa sari tahu ini bisa digunakan untuk mengganti bahan penggumpal atau biang tahu. Air dalam pembuatan tahu sangat penting peranannya, umumnya air digunakan untuk mencuci kedelai, merendam biji kedelai, campuran sewaktu penggilingan biji kedelai, dan perebusan biji kedelai. Agar tidak merusak kualitas rasa tahu, air yang digunakan sebaiknya air sumur bersih yang tidak bercampur kaporit.

\section{b. Peralatan Yang Digunakan}

Beberapa alat yang digunakan dalam memproduksi tahu adalah

1) Bak atau drum untuk merendam

2) Drum untuk memasak sebagai pengganti panic

3) Mesin penggiling

4) Tungku bakar

5) Kain atau saringan

6) Blabak atau cetakan tahu

7) Ember atau baskom plastic besar (untuk tempat menampung air atau mayon)

8) Rak kayu

\section{PEMBAHASAN}

\subsection{Tahapan Pembuatan Tahu}

Dalam produksi tahu tentu di desa Waegeren tentu mempunyai tahapan dalam proses pembuatanya. Dalam proses pembuatan memerlukan bahan dan alat ayang digunakan dalam memproduksi tahu. Pembuatan tahu pada dasrnya terbuat dari kedelai dengan mengkstra proten yang terkandung di dalamnya. Setelah itu pengumpulan susu kedelai 
tersebut dilakukan dengan cara menambahkan bajhan penggumpal berupa asam yakni asam cuka $\left(\mathrm{CH}_{3} \mathrm{COOH}\right)$, batu tahu (CaSO4H2O) Serta larutan bibit tahu (larutan yang direndam selama satu hari).

Adapun proses pembuatan tahu yang ada di Desa Waegeran Kabupaten Buru adaah:

a. Megembil kedelai yang baik dn bagus kulaitasnya kemudian dicuci dengan air bersih. Kemudian kedelai yang sudah dibersihkan kemudian di olah dengan cara ditampi atau menggunakan alat pembersih khusus kedelai.

b. Setelah dibersihkan maka langkah kedua merendam kedelai tersebut dengan air sesuai ukuran kurang lebih 4-7 jam agar kedelai dapat menegembang serta lunak dan mudah untuk digiling.

c. Langkah ketiga menggiling kedelelai yang sudah direndam selama 4-7 jam dan dengan ditambahkan air secukupnya sesuai dengan volume kedelai yang digiling.

d. Langkah selanjutnya adalah kedelai yang sudah digiling kemudian di masak di tungku atau alat pemesak lain dan didihkan selama 20-30 menit. Selama proses memeasak berlangsung maka api dan masakan tetap dijaga untuk menghindari buih dari kedelai.

e. Setelah kedelai selesai di masak maka langkah selanjutnya adalah penyaringan bubur kedelai. Biasanya masyarakat waigeran menggunakan kain untuk menyaring bubur kedelai. Setelah dilakukakn penyaringan maka ampas yang diperoleh dari hasil perasan dibilas dengan air hangat.

f. Setelah sudah mendapatkan sari kedelainya dari hasil penyaringan maka selanjutnya dilakukan penggumpaan dengan menggunaka air asam dengan suhu $50^{\circ} \mathrm{C}$. Setelah itu didimkan sesingga bisa menghasilkan gumpalan yang besar. Kemudian air yang digunakan untuk endapan dibuang dan sebagianya dimanfaatkan untuk penggumpalan selanjutnya. Hasil penyaringan yang diendapkan dalam Wadah yang berupa bak bundar. Proses ini disebut juga dengan pembumbuan. Agar khasil sarinya mengendap dengan baik dan keras dan dicampurkan dengan mayon atau asam cuka. Lama pengendapan kurang lebih $1 / 2$ jam. kemudian air yang meresap di dalam ayakan dipisahkan ketempat lain dengan menggunakan gayun.

g. Hasil endapan yang tersisa selanjutnya dicetak dalam blok yang sudah dialasi dengan kain saingan. Cara pengambilanya dilakukan dengan menngunakan serokan alumanium. Seteah endapan dituang dan sejajar dengan bibir kotak pembatas maka kain sarung pengalas dilipat ke atas dan ditutup lagi dengan alas blak yang lain. Blak yang lain didisi dengan proses yang sama agar menjadi tumpuhkan lima atau lebih. Kemudian didiamkan selama 5 menit.

h. Setelah proses pendiaman selama 5 menit tersebut kemudian dibuka dari balabak atau cetakan dan ditempatkan dalam wadah yag alain atau rak untuk menetesakan air yang mash tersisah saat proses pencetakan. Setelah air yang masih terkandung dalam tahu sudah kering maka tahupun siap dipotong-potong sesuai dengan selera.

\subsection{Biaya Penyusutan Peralatan dan Pendapatan Pengrajin Tahu}

Biaya penyusutan peralatan dihitung berdasarkan nilai baru (harga beli) di bagi dengan Jangka Usia Ekonomi (JUE) pemakaian alat-alat. Hasil 
perhitungan terhimpun dalm tabel 1 . berikut :

Tabel 1. Kebutuhan perlatan dan biaya enyusustan alat tahan lama

\begin{tabular}{lcccr}
\hline \multirow{2}{*}{$\begin{array}{c}\text { Nama dan } \\
\text { Jumlah Alat }\end{array}$} & \begin{tabular}{l} 
Jumlah Harga (Rp) \\
\cline { 2 - 3 }$(\mathbf{R p})$
\end{tabular} & $\begin{array}{c}\text { JUE } \\
\text { (Thn) }\end{array}$ & $\begin{array}{r}\text { Total (Rp) } \\
\text { Biaya Penyu- } \\
\text { sutan (Rp/Bln) }\end{array}$ \\
\hline $\begin{array}{l}\text { Mesin 1 } \\
\text { buah }\end{array}$ & 300.000 & 300.000 & 2 & 12.500 \\
\hline $\begin{array}{l}\text { Ember 15 } \\
\text { buah }\end{array}$ & 7.000 & 105.000 & 1 & 8.750 \\
\hline $\begin{array}{l}\text { Kain Screen } \\
\text { buah }\end{array}$ & 17.500 & 35.000 & 2 & 1458,3 \\
\hline $\begin{array}{l}\text { Blabak 4 } \\
\text { buah }\end{array}$ & 60.000 & 240.000 & 2 & 10.000 \\
\hline $\begin{array}{l}\text { Rak Kayu 1 } \\
\text { buah }\end{array}$ & 300.000 & 300.000 & 5 & 5.000 \\
\hline $\begin{array}{l}\text { Wajan 2 } \\
\text { buah }\end{array}$ & 1 juta & 2 juta & 1 & 166666,7 \\
\hline Biaya Tetap ( Fixed Cost) & 2.980 .000 & 204374,9 \\
\hline
\end{tabular}

Tabel 2. Biaya tidak tetap (variabel cost) perhari

\begin{tabular}{llrr}
\hline \multirow{2}{*}{ Nama Bahan Baku } & \multicolumn{2}{c}{ Bahan Baku } & \multicolumn{1}{c}{ Jumlah } \\
\cline { 2 - 3 } & Satuan & Harga (Rp) & Harga (Rp) \\
\hline Kacang Kedelai & $150 \mathrm{Kg}$ & 7.400 & 1.110 .000 \\
\hline Kulit Padi & 6 Karung & 1.000 & 6.000 \\
\hline Solar & 3 liter & 4.500 & 13.500 \\
\hline Tenaga Kerja & 1 Orang & $72.000 /$ hari & $72.000 /$ hari \\
\hline & & & 1.201 .500 \\
\hline
\end{tabular}

Tabel 3. Biaya tidak tetap (variabel cost) perbulan

\begin{tabular}{lcrr}
\hline \multirow{2}{*}{$\begin{array}{c}\text { Bahan } \\
\text { Baku }\end{array}$} & $\begin{array}{c}\text { Jumlah } \\
\text { Bahan Baku }\end{array}$ & \multicolumn{2}{c}{ Harga Bahan Baku (Rp) } \\
\cline { 3 - 4 } & $\begin{array}{c}\text { Harga } \\
\text { Satuan }\end{array}$ & Jumlah \\
\hline $\begin{array}{l}\text { Kacang } \\
\text { Kedelai }\end{array}$ & $4500 \mathrm{Kg}$ & 7.400 & 33.300 .000 \\
\hline $\begin{array}{l}\text { Kulit } \\
\text { Padi }\end{array}$ & 180 Karung & 1.000 & 180.000 \\
\hline Solar & 90 liter & 4.500 & 405.000 \\
\hline $\begin{array}{l}\text { Tenaga } \\
\text { Kerja }\end{array}$ & 1 Orang & $\begin{array}{r}72.000 / \\
\text { hari }\end{array}$ & $\begin{array}{r}2.160 .000 / \\
\text { bulan }\end{array}$ \\
\hline & & & 36.045 .000 \\
\hline
\end{tabular}

Hasil produksi tahu menggunakan alat moderen dari jumlah kacang kedelai dalam sehari baru mencapai $150 \mathrm{~kg}$ atau sama dengan 36 blabak. Satu blabak biasanya menghasilkan 225 potong tahu. Jadi total produksi tahu dalam sehari adalah 8.100 potong. Di tingkat pasaran harga tahu per blabak adalah Rp 42.500 . Jadi dengan bahan dasar kedelai 150 $\mathrm{kg} /$ hari dapat menghasilkan penjualan sebesar Rp 1.530.000/hari atau sebesar Rp 45.900.000/bulan. Penghasilan bersih atau keuntungan dapat ditentukan dengan :

penjualan - modal kerja + penyusutan

$$
=\operatorname{Rp} 45.900 .000-36045000
$$$$
=\operatorname{Rp} 9.855 .000 \text {, }
$$

Dari hasil perhitungan diatas, maka diperoleh keuntungan dalam sebulan mencapai Rp 9.855.000.

\section{KESIMPULAN}

Kesimpulan yang diperoleh setelah dilakukan pengkajian adalah produksi tahu menggunakan teknologi moderen oleh pengrajin di Desa Waegeren Kabupaten Buru perharinya baru mencapai $150 \mathrm{~kg}$ atau setara dengan 225 potong tahu. Sementara itu, biaya penyusutan peralatan dan pendapatan pengrajin tahu tiap bulannya sebesar Rp. 45.900.000 dan Rp. 9.855.000.

\section{DAFTAR PUSTAKA}

Analisa Finansial dan Ekonomi. (2013). (Online),

(http:/ / fanny.satff.uns.ac.id), diakses tanggal 6 Mei 2019.

Azwar, S. (2010). Metode Penelitian, Yogyakarta : Penerbit Pustaka Pelajar.

Cafah \& Fadhil, G. (2009). Analisis Biaya Produksi Pada Usaha Produksi Tahu di Pabrik Tahu Bandung Raos Cap Jempol, Dramaga, Bogor. Ut-Agricultural Engineering, (Online), (http://repository.ipb.ac.id),

Abstrak diperoleh dari Bogor Agricultural University Scientibic Repository, 2009, Absttract No. 1332.

Definisi Tahu. (2013). (Online), (http://artikata.com/arti352923-tahu.html), diakses 6 Mei 2013.

Meneliti Proses Produksi Pabrik Tahu. (2013).

(Online), 
(http:/ / aditscamp.blogspot.com) , diakses 12 Juni 2019

Sam, Belinda, et al. "Female Feminism in the Customary Island of Buru." Int. J. Sci. Technol. Res 8.8 (2019): 1877-1880

Santoso, W., Utami, P. \& Dumansari (2009). Analisis Pendapatan Dan Biaya Produksi Agroindustri Tahu Di Desa Pandansari Kecamatan Ajibarang Kabupaten Banyumas. Jurnal UMP, (Online), (http:/ /jurnal.ump.ac.id), .

Abstrak diperoleh dari Agritech, 2009, Absttract No. 1/11, diakses 6 Mei 2019

Sarwano. B,\& Saragih. 2007. Membuat Aneka Tahu. Jakarta: Penebar Swadaya.

Tahu. (2013). (Online), (http:/ /id.wikipedia.org/wiki/T ahu), diakses 6 Mei 2019 